\title{
Adoption of improved white yam (Dioscorea rotundata) varieties in Ghana: The role of farm and farmer characteristics
}

P. P. ACHEAMPONG*, A. A-APPIAH, B. N. FRIMPONG, J. HALEEGOAH, E. N. AMENGOR, B. O. ASANTE \& E. OTOO

(P.P.A, A.A-A, B.N.F, J.H, E.N.A, B.O.A \& E.O.: CSIR-Crops Research Institute, Kumasi, Ghana)

*Corresponding author s's email: ppacheampong@gmail.com

\begin{abstract}
Yams (Dioscorea spp) in Ghana are important food staples and the most important non-traditional export crop contributing to foreign exchange and incomes of smallholder producers. Research and development of the crop over the years produced and release three improved Dioscorea rotundata varieties in 2005. However, adoptions of these varieties have been very low. Using cross-sectional data from 544 randomly selected yam farmers and employing the logit model, the farm and farmer characteristics that influence the adoption of yam varieties were assessed. Results revealed the awareness level of improved yam varieties at $50 \%$ and low adoption rate of improved yam varieties at about $6 \%$. Factors found to significantly influence adoption were awareness, education, distance to farm and extension access. The study suggests the need to create more awareness and education on the improved yam varieties in order to sensitize farmers and encourage adoption. There is also the need to improve research extension linkage system to enable technology knowledge transfer to extension staff for easy diffusion to farmers.
\end{abstract}

Keywords: Awareness; extension access; education; logit model; smallholder farmers Original scientific paper. Received 14 May 2020; revised 21 Jun 2021

\section{Introduction}

One of the primary goals of Ghanaian agricultural development programmes and policies is increasing agricultural productivity for accelerated economic growth. Predominantly, majority of Ghanaians depend on agriculture for their livelihoods thus, the agricultural sector has been recognized as important for driving economic growth, overcoming poverty, and enhancing food security (MoFA, 2007; MoFA, 2010). As a result, governments and donor agencies have made efforts over the years to increase production of important food staples. Yams are one important food staple that has received increased attention over the past decades. Yams are ranked second in importance (in tonnage terms) after cassava in staple food production (MoFA, 2016). They are much sought-after food, with an estimated average national annual per capita consumption of $125 \mathrm{~kg}$ (MoFA, 2016). Ghana is the world's largest exporter of yams and exports of Yam from Ghana increased fromUS\$32.599 million in 2017 to US\$37.986 million in 2018 (Ghana Export Promotion Authority, 2019).

Sufficient research efforts have gone into yam improvement programmes due to its

Ghana Jnl Agric. Sci. 56 (2), 61 - 74

GJAS is an Open Access Journal and distributed under the terms of the Creative Commons (CC) License [CC BY 4.0] 
importance to the economy and to the many people that depend on it for livelihoods. Many improved yam varieties and complementary technologies have been developed and released but minimally disseminated to farmers. In Ghana, yams were prioritized under the Accelerated Agricultural Growth and Development Strategy (Technology Sub-committee, 1998). Since then national research programmes such as the Agricultural Services Sub-sector Investment Programme (AgSSIP) in 2000 (World Bank, 2007b), and then the Root and Tuber Improvement and Marketing Program (RTIMP) funded research on Root and Tubers including yams and in 2005 three yam varieties (CRI-Pona, Makron Pona and Kukrupa) which were high yielding disease resistant and acceptable for its culinary characteristics were released. Other agronomic packages such as minisett technology, ridging, minimal staking (trellis) etc, have also been disseminated. In 2008 the West Africa Agricultural Productivity Program (WAAPP) was initiated to develop improved technologies for root and tuber crops of which yams were supported (World Bank, 2007a).

Yam production has been increasing over the years from $12.8 \mathrm{t} /$ ha in 1996 to about $17 \mathrm{t} / \mathrm{ha}$ in 2018 (MoFA, 2019). However, an estimated yield gap of about $32 \mathrm{t} / \mathrm{ha}$ persists due to poor uptake of improved yam technologies (MoFA, 2019). The increased production has been attributed to the expansion of farm lands. Many studies have identified several factors that influence non-adoption of improved varieties in Ghana (Owusu \& Donkor, 2012; Ragasa et al., 2013; Amengor et al., 2018; Acheampong et al., 2019). Factors normally enumerated to influence adoption are farmers' socio-demography characteristics (e.g., farmers' gender, age, education, farm size) and institutional factors (e.g., access to extension services, credit and infrastructure). Specifically, for yam production, Kenyon and Fowler (2000), in their study of factors affecting the uptake and adoption of outputs of crop protection research on yams in Ghana enumerated the many factors affecting the adoption of yam technologies in Ghana. These factors included characteristics of the technology (complexity, compatibility with existing practices, taste and cooking properties), characteristics of farmers' immediate environment (agroclimate, availability of information, access to complementary input) and characteristics of the farmer (education, age, gender).

Subsequently, a lot more, in terms of varietal development and agronomic improvements, have taken place in the yam subsector. However, till date, limited study has been carried out on the patterns of adoption of improved yam technologies in Ghana. The main objectives of this study were to measure the adoption rates of improved yam varieties and complementary agronomic practices produced by national research institutions and to find out about factors influencing adoptions. The study was intended to contribute to understanding factors affecting adoption of improved yam varieties to generate knowledge that would help design policy options to increase improved yam adoption and enhance the development of the yam industry in Ghana.

\section{Materials and Methods}

\section{Study area}

The study was conducted in all yam producing regions in Ghana where yam is produced in significant volumes. Figure 1 presents map of Ghana showing the study area. The study was conducted in 2016 when Ghana had ten regions. 
A proportional probability sampling of districts was done, giving more weight to those with higher yam area and production. The regions and the districts selected fall within three major agro-ecological (Forest, transitional and Guinea Savannah) zones of Ghana. The southern regions comprising Ashanti, Brong Ahafo, Eastern, and Volta experience bimodal cowpea, and root crops (MoFA, 2016).

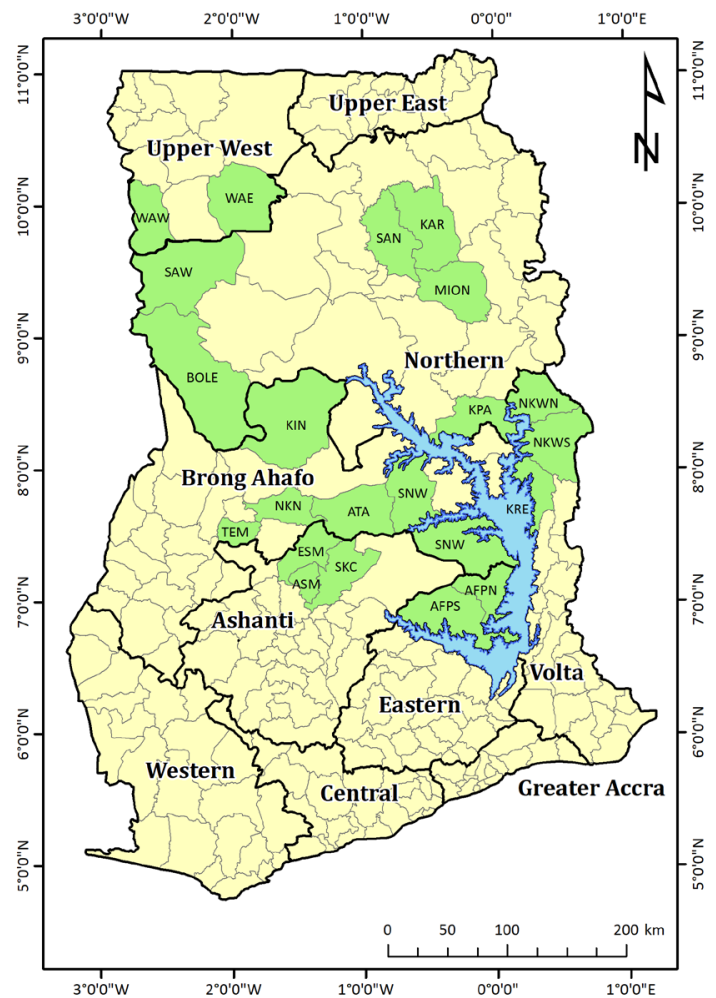

Fig. 1: Map of Ghana showing the study area

\section{Sampling and data source and data collection} Multistage sampling technique was employed to sample the population for the study. The first stage involved the cluster sampling of yam districts within a selected region based rainfall with mean minimum amount of $800 \mathrm{~mm}$ to mean maximum rainfall of $2200 \mathrm{~mm}$ (MoFA, 2016). Mean annual temperature range from $24^{\circ} \mathrm{C}$ to $30^{\circ} \mathrm{C}$. Upper West and Northern regions have unimodal rainfall with mean annual rainfall of $1100 \mathrm{~mm}$ and mean annual temperature of $25^{\circ} \mathrm{C}$. These agro-ecological zones are noted for the production of maize, on volumes of production. The second stage involved simple random sampling of the communities. All communities within the district were listed and through the lottery method the communities were selected. Finally, in the third stage, a simple random sampling 
was again used to select the farmers. A total of 20 districts in seven regions across the country were visited. In each district, four communities that fall within an enumeration area were selected and seven farmers per community were randomly selected. These techniques were employed in order to increase percentage coverage and statistical accuracy and validity. Overall 560 yam farmers were randomly sampled. Due to incomplete information from 16 farmers, data from 544 farmers were used for the analysis

Data were collected through structured interview schedule administered to sampled yam farmers by trained enumerators. Before the actual survey, the structured interview schedule was pretested in non-sampled villages. This questionnaire pretesting was not only used to test the appropriateness of the tool in collecting the required data but also to evaluate the trained enumerators on the capability of administering the structured interview schedule. Information sought included membership of association and other social networks, farmer livestock ownership and control, saving and credit access, access to extension services and other information, income activities, yam technologies knowledge, perceptions and cultivation. Data collected were organized and analyzed using SPSS version 20 and STATA software version 14 . The analyses were segregated based on agro-ecological zones and the statistics performed included frequencies, differences in means and regression analysis.

\section{Analytical framework}

Adoption of improved technologies in this study is defined as the use of any of the three Dioscorea rotundata (CRI-Pona, Makron Pona and Kukrupa) improved varieties that have been released since 2005 and disseminated among farmers over the past five years (2010-2016). Adoption was measured in terms of the number of persons who adopt the technology among the population of yam farmers (adoption rate) (Kaguongo et al., 2011). The logit regression model was used to determine the factors that influence farmers' adoption of improved yam varieties due to the dichotomous nature of the dependent variable. The reasoning for the use of the logit model is as a result of its ability to constrain the utility value of the decision to adopt variables to lie within 0 and 1 (Greene, 2003). Adoption of any of the three Dioscorea rotundata improved variety was captured as a dummy variable with the value of 1 assigned to that farmer and 0 for otherwise. Following Greene (2003), the binary logit for the two choice models can be written as; $y=1$ if $y_{i}>0$ adoption

$y=0 \quad$ if $\quad y_{i} \leq 0 \quad$ non-adoption

Where $y$ indicates adoption of individual farmer $i$

The probability that $y=1$ as a function of the independent variables:

$p=\operatorname{pr}[y=1 \mid \mathrm{X}]=F\left(\mathrm{X}^{\prime} \beta\right)$

Where $\mathrm{X}$ is a vector of explanatory variables, $\beta$ is a vector of parameters to be estimated, $\mathrm{F}$ is the cumulative distribution function of the error term $\varepsilon_{i 1}$. For the logit model $F\left(\mathrm{X}^{\prime} \beta\right)$ the function is the cumulative distribution function of the standard normal distribution. The functional form of Eq. (3) is specified with the logit model as (dyefipged $\frac{b y \exp \left(X^{\prime} \beta\right)}{1+\exp \left(X^{\prime} \beta\right)}$

The specific empirical model for the determination of factors influencing improved yam variety adoption is given as: 


$$
y_{i} \quad \varepsilon_{i} \quad \text { term respectively. }
$$

Where and represents individual farmer's Table 1 shows the description of variables used adoption of improved yam variety and error in the empirical modelling as well as related $y_{i}=\beta_{0}+\beta_{1}$ gender $+\beta_{2}$ age $+\beta_{3}$ education $+\beta_{4}$ experience $+\beta_{5}$ farmsize $+\beta_{6}$ householdsize + $\beta_{7}$ association $+\beta_{8}$ dis $\tan c e+\beta_{9}$ extensionvisit $+\beta_{10}$ awarenese $+\beta_{11}$ plotowner $+\varepsilon_{i}$

hypotheses.

TABLE 1

Description of variables used in the empirical model and hypotheses

\begin{tabular}{|c|c|c|}
\hline Variable & Definition and measurement of variables & Hyp \\
\hline \multicolumn{3}{|l|}{$\begin{array}{l}\text { Dependent } \\
\text { variable }\end{array}$} \\
\hline Adoption & $\begin{array}{l}\text { Dichotomous variable indication } 1=\text { Yes; } \\
0=\text { otherwise }\end{array}$ & \\
\hline \multicolumn{3}{|l|}{$\begin{array}{l}\text { Independent } \\
\text { variables }\end{array}$} \\
\hline Sex & $\begin{array}{l}\text { Sex; } 1 \text { if farmer is a male: } 0 \text { if farmer is a } \\
\text { female }\end{array}$ & +- \\
\hline Age & Age of farmer in years & - \\
\hline Education & Number of years of formal education & + \\
\hline Experience & Number of years in Yam farming & + \\
\hline Household size & Number of persons in the household & + \\
\hline Farm size & Total land holding in hectares & + \\
\hline Association & $\begin{array}{l}\text { If farmer is a member of association }=1 \text {; } \\
0=\text { otherwise }\end{array}$ & + \\
\hline Distance & Distance to input and output market in $\mathrm{km}$ & - \\
\hline Extension Visit & Number of times of extension visit & + \\
\hline Awareness & $\begin{array}{l}\text { If farmer head has knowledge of } \\
\text { improved varieties } 0=\text { otherwise }\end{array}$ & + \\
\hline
\end{tabular}

Plot owner If farmer owns land $=1 ; 0=$ otherwiseand older farmers may be having more The adoption behaviour of farmers as shown in resources like land and finances to also try Table 1 is indicated from established adoption new technologies. Education and experience literature (Ghimire et al., 2015; Langyintuo may influence adoption positively due to the \& Mekuria, 2005; Kassie et al., 2014). Sex ability to use their resources efficiently and is expected to influence adoption positively as male farmers are more likely to adopt new technologies due to access to resources such as land and credit. The influence of age on adoption may be mixed as both the old and the young are likely to adopt. The younger farmers may be eager to try new technologies enhances farmer's ability to obtain, analyze and interpret information. Household size is synonymous with labour availability and can influence adoption positively. Farm size is expected to have positive influence on adoption as farmers with larger farm sizes may be willing to use part to try new technologies. 
Membership of association may affect adoption positively due to ability to information access. Distance to input and output market may have negative effect on adoption as longer distances discourage access to inputs and marketing of produce. Agricultural extension is the most efficient source of information of improved technologies to farmers and therefore extension visit is expected to influence adoption positively.

\section{Results and Discussion}

Socio-demographics of respondents

Table 2 shows the socio-demographic

Forest zone.

TABLE 2

Socio-demographics characteristics of Yam farmers by agro-ecology

\begin{tabular}{|c|c|c|c|c|}
\hline Variable & $\begin{array}{l}\text { Forest Zone } \\
(N=85)\end{array}$ & $\begin{array}{l}\text { Forest Transition } \\
(N=277)\end{array}$ & $\begin{array}{l}\text { Guinea } \\
\text { Savannah }(N=185\end{array}$ & $\operatorname{Pooled}(N=544)$ \\
\hline \multicolumn{5}{|l|}{ Gender (\%) } \\
\hline Male & 84.71 & 88.09 & 95.60 & 90.07 \\
\hline Female & 15.29 & 11.91 & 4.40 & 9.93 \\
\hline \multicolumn{5}{|l|}{ Marital status (\%) } \\
\hline Single & 7.06 & 4.69 & 3.85 & 4.78 \\
\hline Married & 85.88 & 89.17 & 93.41 & 90.07 \\
\hline Divorced & 1.88 & 2.53 & 1.10 & 1.84 \\
\hline Widowed & 5.88 & 3.61 & 1.65 & 3.31 \\
\hline \multicolumn{5}{|l|}{ Residence status(\%) } \\
\hline Native & 43.53 & 61.37 & 91.76 & 68.75 \\
\hline Settler & 56.47 & 33.61 & 8.24 & 31.25 \\
\hline \multicolumn{5}{|l|}{ Level of education(\%) } \\
\hline None & 34.12 & 55.23 & 76.92 & 59.19 \\
\hline Junior High & 30.59 & 24.91 & 9.34 & 20.59 \\
\hline Senior High & 31.76 & 16.25 & 12.64 & 17.46 \\
\hline Tertiary & 3.53 & 2.53 & 1.10 & 2.21 \\
\hline University & 0.00 & 1.03 & 0.00 & 0.55 \\
\hline \multicolumn{5}{|c|}{ Other descriptive statistics (Mean) } \\
\hline Age (years) & 49.10 & 47.74 & 41.71 & 45.60 \\
\hline Household size (count) & 8.28 & 8.69 & 10.56 & 9.27 \\
\hline Experience (years) & 25.33 & 21.43 & 22.14 & 21.99 \\
\hline Education (years) & 7.10 & 3.80 & 2.64 & 3.94 \\
\hline
\end{tabular}

characteristics of respondents by agroecological zone. Majority $(90 \%)$ of the yam farmers interviewed were males with just a few $(10 \%)$ being females. Yam production has long been dominated by males (Martin et al., 2013). The Forest zone had the highest proportion of female farmers (about 15\%) followed by the Forest Transitional zone (about 11\%). Majority of the farmers across the agro-ecological zones were married with Guinea Savannah zone recording the highest proportion of farmers that were married followed by transition and 


\begin{tabular}{llrcrcc} 
Farm size(acres) & \multicolumn{2}{c}{6.40} & 4.34 & 5.00 & 4.88 \\
\hline Again, majority & $(69 \%)$ & of the farmers Adoption of improved varieties and good
\end{tabular}
interviewed were natives of their respective agronomic practices settlements. By agro-ecological zone, Guinea Savannah had the highest proportion $(92 \%)$ of farmers being natives followed by transition zone and then Forest zone respectively. Majority (59\%) of the farmers interviewed had no formal education with farmers in the Guinea zone having majority (77\%) with no formal education followed by transition zone of about $55 \%$. The Forest zone had $32 \%$ and $31 \%$ of respondents attaining junior high school level and senior high school level of education respectively. Majority of respondents from Forest Transition and Guinea Savannah zones had not had formal education. Mean age of yam farmers was about 46 years with farmers from the forest zone having the highest mean age of 49 years followed by Forest Transition zone with a mean age of 47 years. Guinea Savannah zone had the youngest farmers with a mean age of 42 years.

Yam producers had been cultivating yam for quite long and had attained some appreciable level of experience in yam production. Mean experience in yam production was 22 years. Forest zone farmers were the most experienced with 25 years in farming. The mean farm size was about 5 acres ( 2 ha). Farmers in the forest zone had the largest farm size of 6.4 acres (2.56 ha). The Ministry of Food and Agriculture (2016) reports of average farm size of a Ghanaian farmer of about 2 hectares. This suggests that the farm sizes of yam farmers fall within the national average small farm size.

Awareness and Adoption of improved yam varieties

Without farmers' knowledge of a new variety, the adoption possibility is impossible. Figure 2 presents the awareness level of respondents and their corresponding adoption of improved yam varieties by agro-ecological zones. The results showed that $50 \%$ of all yam farmers interviewed were aware of the three Dioscorea rotundata improved varieties. The forest zone had $87 \%$ of farmers who were aware of the three Dioscorea rotundata varieties followed by farmers in the Forest Transitional zone. Guinea Savannah zone had only $32 \%$ of farmers who were aware of the improved yam varieties. Adoption rate of the three improved Dioscorea rotundata varieties was $6.25 \%$ across the study area. About $13 \%$ of respondents from the Forest zone had adopted the varieties. Adoption of improved yam varieties across the yam belt (Nigeria, Benin, Ivory Coast and Ghana) of West Africa has been reported to be less than 10\% (Mignouna et al., 2014). Therefore, the finding from this study corroborates with the general low adoption of improved yam varieties across West Africa. The results also showed where the awareness rate was high, for instance in the Forest Zone, the adoption rate was also hioh

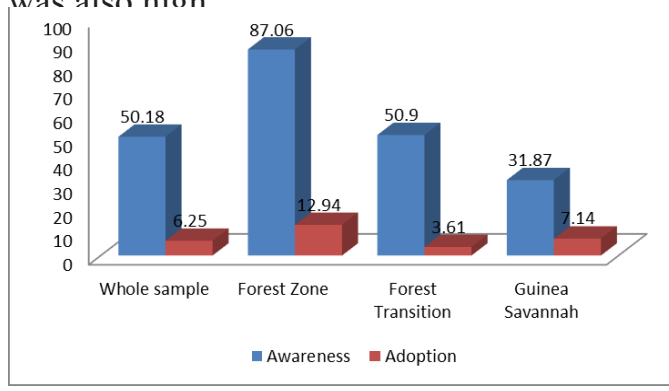

Fig. 2: Yam farmers' awareness and adoption rate of 
improved yam varieties by agroecological zone

Table 3 shows the adoption spread of various improved yam varieties. CRI-Pona and Mankrong-Pona were the two most popular improved varieties cultivated by farmers. About $9 \%$ of the farmers interviewed grew CRI-Pona in the Forest zone followed by about $1 \%$ at the Forest Transition zone and $0.55 \%$ at the Guinea Savannah zone. Makrong-pona was cultivated by $6 \%$ of farmers from the Guinea Savannah zone and only $1 \%$ of farmers from the forest and the transition zones. Few farmers from Forest Transition and Guinea Savannah zones cultivated Agric variety (improved varieties that farmers could not name) The indigenous varieties were mostly grown in all the ecological zones.

TABLE 3

Adoption of improved yam varieties by agro-ecological zones, 2016 major season

\begin{tabular}{lllll}
\hline Varieties & $\begin{array}{l}\text { Forest Zone } \\
(N=85)\end{array}$ & $\begin{array}{l}\text { Transition } \\
\text { Zone }(N=277)\end{array}$ & $\begin{array}{l}\text { Guinea Savannah } \\
\text { Zone }(N=182)\end{array}$ & $\begin{array}{l}\text { All Zone } \\
(N=544)\end{array}$ \\
\hline CRI-Pona & 9.41 & 1.08 & 0.55 & 2.21 \\
Mankrong-Pona & 1.18 & 1.44 & 6.04 & 2.94 \\
Agric & 0.00 & 0.36 & 0.55 & 0.37
\end{tabular}

Indigenous

89.41

97.11

Total ared of yam

98949.5

100.00

Adoption intensity of improved yam varieties

The intensity of adoption was estimated by the proportion of yam plots that were devoted to the cultivation of improved yam varieties. Table 4 shows the area of cultivation of the various improved yam varieties during the 2016 major season. Just about 2.9\% and 2.8\% each of the total yam area were put to the cultivation of Mankrong-Pona and CRI-Pona respectively. Agric variety covered about $0.2 \%$ of the total yam area of the country. The indigenous varieties covered $94 \%$ of the yam area in Ghana.

TABLE 4

Area planted to specific yam varieties in 2016 major season

\begin{tabular}{lll}
\hline Variety & Area(ha) & Total (\%) \\
\hline Improved variety & & \\
CRI-Pona & 48.00 & 2.82 \\
Makrong-Pona & 50.00 & 2.94 \\
Agric/MoFA & 3.22 & 0.19 \\
All improved variety & 101.00 & 5.95 \\
Indigenous variety & & \\
Indigenous variety & 1598.50 & 94.05
\end{tabular}

Awareness and Adoption of agronomic practices

Many improved agronomic practices have been introduced to farmers. They are mainly used in addition to the improved yam varieties for them to exhibit their potential. Farmer awareness and adoption of these technologies were sought. Figure 3 presents the knowledge and use of recommended agronomic practices by yam farmers across the region.

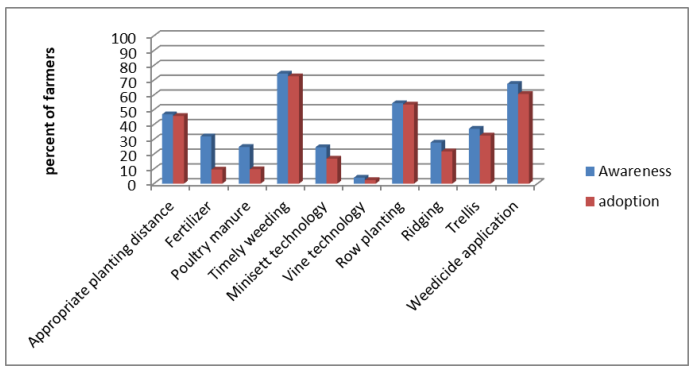

Fig. 3: Adoption of improved yam agronomic technologies $(\mathrm{N}=544)$ 
The descriptive statistics showed that $46 \%$ of respondents were aware of appropriate planting distance of $1 \mathrm{~m}$ by $1 \mathrm{~m}$ for maximum plant population and $46 \%$ said they planted at that distance in 2016 major season. The rate of awareness of fertilizer application on yam fields was $32 \%$ and $9 \%$ reported using fertilizers. With timely control of weed, out of the $74 \%$ of the farmers that had knowledge of it quite an appreciable number (73\%) said they controlled weeds on time. About $61 \%$ out of the $67 \%$ of the farmers that had knowledge of weedicides applied it on their yam fields. Regarding row planting out of the $54 \%$ of farmers that had knowledge of it, 53\% applied row planting. On ridging $27 \%$ of farmers were aware and $21 \%$ had adopted it. With minisett technology (cutting seed yams into pieces of 30 to $50 \mathrm{~g}$ ) (IITA, 1985), 24\% of respondents said they were aware of it and 16\% reported that they had adopted it. Yam minisett technology was developed in the 1980s and has been introduced to farmers over many years (IITA, 2004). The low knowledge and low rate of adoption is very surprising. Nonetheless, many authors (Kambaska et al., 2009; Ajieh, 2012) have bemoaned the low adoption of minisett technology despite being the most effective method for rapid multiplication of seed yam for increased and sustained production of the crop. Vine technology (tuber-less yam propagation technique where yam is propagated through vine cuttings using carbonized rice husks as growth medium) (Otoo et al., 2016) was recently introduced to farmers. Only 4\% reported having knowledge of it and 2\% said they practiced it.

Factors affecting adoption of improved yam varieties

Mean differences between adopters and nonadopters were analyzed and the results are presented in Table 5. Mean difference between the age of adopters and non-adopters was four years and it was significant. Adopters were older than non-adopters suggesting that adopters might be more experienced and more resourceful in terms of land and funds to try out new varieties. Concerning experience in farming, the mean difference between adopters and non-adopters was significant. Adopters had more experience in yam farming than nonadopters.

Farmers who did not grow improved yam varieties (non-adopters) were significantly better educated than the adopters by having about two additional years of schooling on average. The less educated may have been the target of extension officers. Similar findings were reported in Tanzania on adoption of improved wheat (Mussei et al., 2001). As regards awareness, the mean difference between adopters and non-adopters was significant. Adopters were more aware of the improved yam varieties than non-adopters.

The distance to input and output market was significantly shorter for adopters than nonadopters. The result here supports the assertion that adopters of improved varieties are nearer to input and output market. Input and output markets influence the adoption of improved agricultural technologies. The further away a village or a farmer is from input and output 
markets, the lesser the likelihood that they will adopt high yielding technology.

TABLE 5

Mean differences between adopters and non-adopters of improved yam varieties

\begin{tabular}{|c|c|c|c|c|c|}
\hline Variable & $\begin{array}{l}\text { Adopters } \\
(N=34) \\
(6.25)\end{array}$ & $\begin{array}{l}\text { Non-adopters } \\
(N=510) \\
(92.46 \%)\end{array}$ & Diff. & $t$-stats & $\chi^{2}$ \\
\hline \multicolumn{6}{|c|}{$\begin{array}{l}\text { Socio-demographics } \\
\text { Sex }\end{array}$} \\
\hline Male & 0.83 & 0.91 & & & \multirow[t]{7}{*}{2.42} \\
\hline Female & 0.17 & 0.09 & & & \\
\hline Household size & 9.82 & 9.19 & 0.63 & 0.76 & \\
\hline Age & 49.94 & 45.63 & $4.02 * *$ & 1.93 & \\
\hline Experience & 24.14 & 20.57 & $3.57^{*}$ & 1.71 & \\
\hline Education & 2.29 & 4.08 & $1.79^{* *}$ & 2.14 & \\
\hline Association & 0.63 & 0.53 & 0.09 & 1.20 & \\
\hline \multicolumn{6}{|c|}{ Farm characteristics } \\
\hline Farm Size & 5.61 & 4.83 & 0.77 & 0.25 & \\
\hline Plot Owner & 0.73 & 0.76 & 0.03 & 0.51 & \\
\hline \multicolumn{6}{|c|}{$\begin{array}{l}\text { Institutional factors } \\
\text { Extension access }\end{array}$} \\
\hline $\begin{array}{l}\text { Yes } \\
\text { No }\end{array}$ & $\begin{array}{l}0.21 \\
0.79\end{array}$ & $\begin{array}{l}0.78 \\
0.22\end{array}$ & & & \multirow[t]{2}{*}{0.003} \\
\hline $\begin{array}{l}\text { Extension visit } \\
\text { Awareness }\end{array}$ & 2.92 & 2.84 & 0.07 & 0.23 & \\
\hline $\begin{array}{l}\text { Yes } \\
\text { No }\end{array}$ & $\begin{array}{l}0.88 \\
0.12\end{array}$ & $\begin{array}{l}0.49 \\
0.51\end{array}$ & & & $19.05^{* * *}$ \\
\hline Distance & 9.92 & 13.68 & $3.75^{*}$ & 1.76 & \\
\hline
\end{tabular}

The logit estimates of the factors influencing adoption of improved yam varieties are presented in table 6 . The pseudo R-squared which is explained as the variance in the dependent variable that is predictable from the independent variables is 0.16 . McFadden (1974), opined that a value of 0.2-0.4 indicates excellent model fit, thus the logit model presented has quite a good fit. The results revealed that years of education negatively and significantly influenced the adoption of improved yam varieties. The implication is that the probability of adoption is more likely with those who have not spent many years in school. These yam farmers from the descriptive results were older and more experienced and probably more resourceful to try new technology that would give them higher yields than what 
they had. The result is consistent with many (Uematsu, 2010: Tesfaye et al., 2016) adoption studies that found negative effect of years of education on adoption.

TABLE 6

Logit estimates of factors influencing the adoption of improved yam varieties

\begin{tabular}{lll}
\hline Variable & Coefficient & Std. Err. \\
\hline Age & 0.009 & 0.019 \\
Education & $-0.100^{* * *}$ & 0.042 \\
Household size & 0.018 & 0.034 \\
Experience & 0.010 & 0.019 \\
Farm Size & 0.003 & 0.009 \\
Distance & $-0.036^{*}$ & 0.022 \\
Gender & -0.392 & 0.568 \\
Marital Status & -0.151 & 0.597 \\
Association & 0.423 & 0.376 \\
Awareness & $2.410^{* * *}$ & 0.557 \\
Plot Owner & 0.062 & 0.395 \\
Extension & $-0.789 * *$ & 0.430 \\
Extension Visit & -0.023 & 0.086 \\
Constant & $-3.550 * * *$ & 1.192 \\
Observations & 544 & \\
Pseudo & 0.16 & \\
R-Squared & \\
Log Likelihood & -121.24 & \\
*significant at 10\%, $*$ significant at $5 \%, * * *$ \\
significant at 1\%
\end{tabular}

Improved varieties awareness is positive and significant at $1 \%$. The probability of adoption increases with increased awareness. The importance of information cannot be underestimated in the adoption process. The importance of awareness in agricultural technology adoption has been suggested by many studies in Africa (Kaliba et al., 2000; Shiferaw et al., 2008) and these findings corroborate with the findings in this study.
Also, increased understanding of the benefits of technology increases probability of adoption as it reduces fear of participation. The coefficient of extension access was negative and significant contrary to expectation. This indicates that farmers receiving visits by extension are less inclined to the adoption of improved yam varieties. This suggests that extension workers may not be recommending improved yam varieties, which may be through lack of knowledge of the technologies by the extension agents. It may also imply that farmers are dismissing the information given by extension workers concerning improved yam technologies. The coefficient of distance was negative and significant, suggesting that shorter distances to input and output market are important to adoption of improved yam varieties. The probability of adoption is more likely with farmers who travel short distances to access market. Yam is very bulky and has short shelf life and so the ability to access market conveniently serves as incentive to adopting new varieties which are supposed to give more yields. Udoh and Kormawa (2009), analyzed the determinants for cassava production expansion in the semi-arid zone of West Africa and found out that distance to nearby urban markets was a major influence on cassava adoption in Ghana, Chad, Nigeria, Burkina Faso.

\section{Conclusion and Recommendations}

The study has assessed adoption rates of improved technologies of yam and factors influencing adoption. The results revealed that the overall adoption rate was $6 \%$. The adoption rate in the Forest zone was $13 \%$, that in the Forest Transition was about $4 \%$ and the rate in the Guinea savannah zone was $7 \%$. Adoption rates of improved yam varieties are low in Ghana. The awareness rate of $50 \%$ was also 
low suggesting that low adoption may be due to low awareness of the improved varieties and complementary agronomic practices. Pursuing awareness creation by extension across yam producing areas is important to encourage adoption.

The results revealed that the probability of yam adoption is significantly affected by awareness, distance to input and output market, extension and years of education. It was revealed that awareness affected adoption of improved yam varieties positively and significantly at $1 \%$. The importance of awareness creation cannot be underestimated in adoption process. Research institutions and extension should be resourced to conduct demonstrations and organize field schools to increase awareness for increased adoption. Distance to input and output market appeared to influence adoption negatively. Shorter distance to market means that produce gets to marketers on time avoiding product deterioration and also reducing transportation cost. Government and private sector should create an enabling environment such as improving road networks and providing infrastructure for smallholder producers to get better access to markets to reliably sell their produce at the required prices. This in turn will encourage farmers to cultivate high yielding yam varieties to increase the quantity of produce.

The results also point to negative impacts of extension contact on adoption of improved yam varieties. This unusual expectation means that extension provision on improved yam technologies is lacking. Either the extension agents are not well educated on the improved technologies of yam or they are biased towards the existing technologies of yam. Agricultural extension agents need training on new technologies to enable the impact of knowledge acquired to farmers. There is a need for the government to strengthen research-extension linkage by providing funding for capacity building.

Since this study could not capture other data needs such as technology characteristics (eg complexity, compatibility with existing practices, taste and cooking properties) and cost of technology, further studies to fill these data gaps are recommended.

\section{Acknowledgement}

We acknowledge the funding provided by the West Africa Agricultural Productivity program for this study.

\section{REFERENCES}

Acheampong, P.P., Amengor, N.E., Frimpong, B,N., Adu-Appiah, A., Haleegoah, J., Adogoba, D. \& Nimo-Wiredu, A. (2019) Determinants of Adoption of Improved Sweetpotato Varieties in Ghana. Ghana Journal of Agricultural Economics and Agribusiness 2 (1), 65 - 85. ISSN 2637-3521.

Amengor, N.E., Asante, B. O., Adofo, K., Acheampong, P. P., Frimpong, N. B., NimoWeridu, A., Adogoba. D., Haleegoah, J., Adu-Appiah, A., Baafi, E. \& Sagoe, R. (2018) Adoption of Improved Sweetpotato Varieties in Ghana. Asian Journal of Agricultural Extension, Economics \& Sociology 23 (3), 1 - 13.

Adu, S.V. (1992) Soils of the Kumasi Region of Ghana; Soil Research Institute: KwadasoKumasi, Ghana.

Ajieh P.C. (2012) Adoption of yam (Discorea spp) minisett technology in Delta State, Nigeria, Agriculture Tropical et Subtropical 45 (2), $84-88$.

Batz J., Peters K. \& Janssen W. (1999) The influence of technology characteristics on the rate and speed of adoption, Agricultural Economics 21 (2), $121-30$. 
GEPA (2019) https://www.gepaghana.org/cms/wpcontent/uploads/2019/10/Potential-marketYam-2019-1.pdf (assessed 23/03/2020)

Greene, W.H. ( 2003) Econometric analysis. Fifth edition. Prentice Hall, New Jersey.

Ghimire, R., Wen-chi, H. \& Shrestha, R.B. (2015) Factors Affecting Adoption of Improved Rice Varieties among Rural Farm Households in Central Nepal. Rice Science 22 (1), 35 - 43.

IITA (2004) "Annual Report of the International Institute of Tropical Agriculture", IITA report, Ibadan, Nigeria, http:/www.iita.org/cms/ articlefiles/92-Project $\% 20 \mathrm{E} \% 202004$.pdf

IITA (1985) Root and tuber improvement program. International Institute of Tropical Agriculture. Research Highlights 1981-1984, Ibadan, Nigeria.

Kassie, M., Ndiritu, S. W. \& Stage, J. (2014) What determines gender inequality in household food security in Kenya? Application of exogenous switching treatment regression. World Development 56, $153-171$.

Kaguongo,W., Ortmann, G., Wale, E., Darroch, M. \& Low, J. (2012) Factors influencing adoption and intensity of adoption of orange flesh sweet potato varieties: Evidence from an extension intervention in Nyanza and Western provinces, Kenya. African Journal of Agricultural Research 7 (3), 493 - 503.

Kenyon, L. \& Fowler, M. (2000) Study of factors affecting the uptake and adoption of outputs of crop protection research on yams in Ghana. Final Technical Report, R7504 (ZA0354) (NRI - A0897). Natural Resources Institute University of Greenwich, 1 November 1999 - 31 May 2000.

Kaliba, A.R.M., Verkuijl, H. \& Mwangi, W. ( 2000) Factors affecting adoption of improved maize seeds and use of inorganic fertilizer for maize production in the intermediate and lowland zones of Tanzania. Journal of Agriculture and Applied Economics 32 (1), 35 - 47.

Kambaska, K.B., Santilata, S., Trinanth, M. \& Debashrita, P. (2009) Response of vine cuttings to rooting in different months in three Dioscorea species. Journal of Nature and Science 7, $48-51$.

Langyintuo,A.S. \& Mekuria, M. (2005) Accounting for neighborhood influence in estimating factors determining the adoption of improved agricultural technologies. Selected Paper prepared for presentation at the American Agricultural Economics Association Annual Meeting, Providence, Rhode Island, July 2427, 2005.

Martin, A., Forsythe, L., Addy, P.S., Aniaku, V., Opoku-Asiama, M., Ironkwe, A. G., Ewuziem, J.E.,\& Onwuka, S. (2013) Gender and Social Diversity Analysis of the Yam Value Chain in Ghana and Nigeria. Summary Report, YIIFSWA, December 2013

McFadden, D. (1974) Conditional logit analysis of qualitative choice behavior. pp. $105-142$ in P. Zarembka (ed.), Frontiers in Econometrics.

MoFA (Ministry of Food and Agriculture) (2007) Food and Agriculture Sector Development Policy (FASDEP II), MoFA, Accra, Ghana.

MoFA (Ministry of Food and Agriculture) (2010) Medium Term Agriculture Sector Investment Plan (METASIP) document (2010). Ministry of Food and Agriculture, Accra, Ghana, September, 2010.

MoFA (Ministry of Food and Agriculture) (2016) Agriculture in Ghana. Facts and Figures, Statistics, Research and Information Directorate (SRID), Accra, Ghana.

Mignouna D. B., Akinola A. A., Suleman I., Nweke 
F.,\& Abdoulaye T. (2014) Yam: A Cash Crop in West Africa. YIIFSWA Working Paper Series No. 3, Yam Improvement for Income and Food Security in West Africa International Institute of Tropical Agriculture. ISBN 978978-8444-38-1.

Mussei, A., Mwanga, J., Mwangi, W., Verkuijl, H., Mongi, R. \& Elanga, A. (2001) Adoption of improved wheat technologies by small scale farmers in Mbeya District, Southern Highlands, Tanzania. Mexico, D.F. Tanzania: International Maize and Wheat Improvement Center (CIMMYT) and the United Republic of Tanzania.

Otoo E, Anyakanmi, T.G., Kikuno, H. \& Asiedu, R. (2016) In Vivo Yam (Dioscorea spp.) Vine Multiplication Technique: The Plausible Solution to Seed Yam Generation Menace. Journal of Agricultural Science 8 (2), 88 - 97.

Owusu, V. \& Donkor, E. (2012) Adoption of Improved Cassava Varieties in Ghana. Agricultural Journal 7 (2), 146 - 151.

Ragasa, C., Dankyi, A., Acheampong, P., NimoWiredu, A., Chapoto,A., M. Asamoah, M. \& Tripp, R. (2013) Patterns of Adoption of Improved Rice Technologies in Ghana. Working Paper 35, International Food Policy Research Institute (IFPRI), Ghana Strategy Support Program, July 2013, p. 33.

Saha L., Alan L.H. \& Schwart R. (1994) Adoption of emerging technologies under output uncertainty, American Journal of Agricultural Economics 76 (4), 836 - 846.
Shiferaw, B., Kebede, T.A. \& You, L. (2008) Technology adoption under seed access constraints and the economic impacts of improved pigeonpea varieties in Tanzania. Agricultural Economics 39 (3), 309 - 323.

Technology Sub-committee (1998) Facilitating access to agricultural technology. Draft final report to the AgSSIP Task Force. November (mimeo).

Tesfaye, S., Bedada, B. \& Mesay, Y. (2016) Impact of Improved Wheat Technology Adoption on Productivity and Income in Ethiopia. African Crop Science Journal 24 (1), 127 - 135

Udoh, E. J.\& Kormawa, P. M. (2009) Determinants for cassava production expansion in the semi-arid zone of West Africa. Environment, Development and Sustainability 11 (2), 345 357.

Uematsu, H. \& Mishra, A. (2010) Can education be a barrier to technology adoption? Selected Paper prepared for presentation at the Agricultural \& Applied Economics Association 2010 AAEA, CAES, \& WAEA Joint Annual Meeting, Denver, Colorado, 25 - 27.

World Bank (2007a) First phase of a support program to the West Africa Agricultural Productivity Program (WAAPP). Project information document. Report No: 43482. Washington, D.C.

World Bank ( 2007b) Implementation completion and results report (IDA-34050 IDA-3405a) Republic of Ghana for an Agricultural Services Subsector Investment Project. Report No: ICR0000589. Washington, D.C. 